"the only person who actually understood the Palestinian issue" and says, "She saved my life." A Palestinian colleague writes, "This extremely secular Jewish woman radiated spirituality through writing, service, and personal and family life."

Cheryl's husband, Marty, died in June 2016. She is survived by her son, Scott Rubenberg, his wife and their two children, and by Ayman Wishah and his wife and two children. She will be remembered for her meticulous scholarship, her keen intelligence, her courage, her graciousness, her generosity, and her deep commitment to Palestinian human rights. ${ }^{1}$ so

DOI:10.1017/rms.2018.20

Valerie J. Hoffman

The University of Illinois at Urbana-Champaign

\title{
Jack G. Shaheen
}

1935-2017

Pioneering author and media critic, Dr. Jack Shaheen devoted his life to identifying and contesting damaging stereotypes of Arabs and Muslims in American media and pop culture. Arabs and Muslims were offered up as cartoon caricatures-dagger wielding, evil, ridiculous, hypersexualized, inhumane and incompetent "others." Dr. Shaheen quickly recognized their shared genealogy to the portrayals of other racialized groups including Jews, Native Americans, Asian Americans, Latinos, and African Americans. Always in the spirit of engaged dialogue, he was outspoken in defense of any group that was wrongfully stereotyped and vilified.

When people asked what brought him to explore the Arab stereotype, shaheen would quote the calls of his own young children as they followed morning cartoons-"Daddy, daddy, there are bad Arabs on TV!" The son of Lebanese immigrants, Shaheen set out to understand, document, and combat the stereotype. To his amazement, he found the demeaning stereotype everywhere-in editorial cartoons, advertisements, toys, children's books,

${ }^{1}$ I would like to thank the following individuals for their comments and assistance: Khalil Barhoum, Marwan Diab, Mick Dumper, Richard Falk, Elaine Hagopian, Brian Nelson, John Quigley, Ghassan Rubeiz, Rabbi Bruce Warshal, and especially Scott Rubenberg, Lisa Rubenberg, Ayman Wishah, Hatem and Hana, Janet Moyer, and Susan Waltz. 
comics, and, most insidiously, due to the power of video images, on TV and Film.

When he first interviewed TV producers about this stereotyping as part of research for his book The TV Arab (Popular Press, 1984), Shaheen was met with denial. It is just entertainment, they said. Everyone needs a bad guy. It was his tireless questioning that raised awareness and brought accountability to the industry. Thanks to his efforts, Arab and Muslim stereotyping is now identified as a critical issue, addressed in university settings, and increasingly taken into account by media stakeholders.

Born in 1935 in Pittsburgh, Pennsylvania, Shaheen earned degrees from the Carnegie Institute of Technology, Pennsylvania State University, and the University of Missouri, and retired Professor Emeritus at the University of Southern Illinois Edwardsville.

A U.S. Army veteran, Shaheen also served as a founding board member of the American-Arab Anti-Discrimination Committee, the Arab American National Museum and as the primary consultant for the critically hailed films Syriana and Three Kings. He made it his life-long career to disrupt the negative stereotypes associated with the Arab community. His work has inspired generations of emergent Arab American and Muslim American independent writers, illustrators, and filmmakers.

Shaheen regularly discussed media stereotypes on national programs and networks such as CNN, MSNBC, National Public Radio, Nightline, Good Morning America, 48 Hours, and The Today Show. And he served as a consultant for motion picture and television companies such as DreamWorks, Warner Brothers, Hanna-Barbera Productions, and Showtime. He wrote op-ed pieces for newspapers and contributed over three hundred essays for feature magazines published in major US and international venues. He gave over one thousand lectures throughout the US and on three continents.

His print publications include: The Survival of Public Broadcasting (Southern Illinois University, 1973), Nuclear War Films (Southern Illinois University Press, 1978), The TV Arab (Popular Press, 1984), Arab and Muslim Stereotyping in American Popular Culture (Georgetown University Center for Muslim-Christian Understanding, 1997), Guilty: Hollywood's Verdict on Arabs after 9/11 (Olive Branch Press, 2008), the award-winning Reel Bad Arabs: How Hollywood Vilifies a People (Olive Branch Press, 2001), and A is for Arab: Archiving Stereotypes in U.S. Popular Culture (The Asian/Pacific/American Institute, NYU, 2012), which was adapted as a traveling exhibit. In 2006, the Media Education Foundation produced a video documentary based on Reel Bad Arabs by the same title. 
His extensive research collection, donated to NYU, provides valuable documentation of the representations of Arabs and Muslims in US popular culture and mass media from the late nineteenth to the twenty-first century. The Jack G. Shaheen Collection on Arabs in US Film and Television located at the NYU Tamiment Library \& Robert F. Wagner Labor Archives, Hagop Kevorkian Center for Near Eastern Studies, and Asian/Pacific/American Institute contains nearly 3,000 motion pictures (spanning from latenineteenth century silent films to contemporary Hollywood productions) and television programs (including comedies, dramas, cartoons, as well as commercials) on DVDs and VHS tapes. Paper ephemera in the archive comprises editorial cartoons, motion picture posters and stills, comic books, and advertisements. Also included in the archive are movie/TV scripts, law cases, books, and magazines, as well as toys and games.

Professor Shaheen is survived by his loving wife of fifty-one years, Bernice M. Shaheen, their two children Michael Shaheen and Michele Tasoff, and their four grandchildren.

His commitment to supporting emergent media scholars and professionals lives on in The Jack G. \& Bernice M. Shaheen Endowed Media Scholarship Fund at CAAP. The scholarship, which to date has had seventy recipients, supports Arab American students majoring in mass communications, journalism, and film.

DOI:10.1017/rms.2018.21

John Kuo Wei Tchen New York University 